\title{
Association between vitamin D plasma concentrations and VDR gene variants and the risk of premature birth
}

\author{
Letícia Veríssimo Dutra ${ }^{1}$, Fernando Alves Affonso-Kaufman², Fernanda Ramires Cafeo ${ }^{2}$, Milene Saori Kassai ${ }^{3}$, \\ Caio Parente Barbosa ${ }^{4}$ (D) Francisco Winter Santos Figueiredo ${ }^{1}$ (D) Fabíola Isabel Suano-Souza ${ }^{3}$ (D) and \\ Bianca Bianco ${ }^{2,4^{*}}$ (D)
}

\begin{abstract}
Background: Premature birth is the main cause of mortality in children under 1 year, and vitamin D deficiency during gestation is associated with prematurity. The effects of vitamin D are mediated by its receptor, which is encoded by the VDR gene. VDR variants — such as single nucleotide variation (SNV) — are associated with increased risk of prematurity, but there are conflicting results. We evaluated serum vitamin $D$ concentrations and the frequency of Taql/A>G, Bsml/C $>\mathrm{T}, \mathrm{Apal} / \mathrm{C}>\mathrm{A}$, and Fokl/A $>\mathrm{T} V D R$ variants in mothers and preterm (PTN) and fullterm (FTN) newborns.

Methods: We conducted a case-control study comprising 40 pairs of mothers and their PTNs (gestational age $<32$ weeks and/or weight $<1500 \mathrm{~g}$ ), and 92 pairs of mothers and FTNs as controls. Genotyping was performed by realtime PCR, and plasma vitamin D concentrations were measured by electrochemiluminescence.

Results: Vitamin D levels were significantly lower in PTN mothers. Genotypes Taql/GG and Bsml/TT, and haplotypes AAG (Taql/A-Apal/A-Fokl/G) and GCA (Taql/G-Apal/C-Fokl/A) were significantly more frequent in PTN mothers, and genotypes Taql/AG, Apal/AA, and Fokl/AG resulted in significantly lower vitamin D levels. Genotypes Bsml/TT and Apal/AA were associated with vitamin D deficiency and 2.36 and 7.99 times greater likelihood of PTB, respectively. Vitamin D levels were also lower in PTNs, although it was not statistically significant. Genotypes Bsml/TT, Apal/AA, and Fokl/GG, and haplotype GAG (Taql/G-Apal/A-Fokl/G) were significantly more frequent in PTNs. Those with Fokl/ GG genotypes had significantly lower vitamin D levels.
\end{abstract}

Conclusions: VDR variants contribute to variations in vitamin D concentrations and the increased risk of prematurity.

Keywords: Genetic variant; Vitamin D; Premature birth; gestation; newborns.

\section{Introduction}

A preterm birth is defined as a delivery that occurs before 37 weeks' gestation, and can be classified as late preterm (36-34 weeks), very preterm (28-34 weeks), or extremely preterm (less than 28 weeks) $[1,2]$. Prematurity is the main cause of death among children under 5 years of age [3], and preterm infants may present with

\footnotetext{
* Correspondence: bianca.bianco@hotmail.com; bianca.bianco@fmabc.br ${ }^{2}$ Medical Student, Faculdade de Medicina do ABC, Santo Andre, Brazil ${ }^{4}$ Department of Collective Health, Discipline of Sexual and Reproductive Health and Populational Genetics, Faculdade de Medicina do ABC, Santo Andre, Brazil

Full list of author information is available at the end of the article
}

early and late health complications involving the immune, respiratory, cardiovascular, gastrointestinal, and endocrine systems, as well as growth and developmental problems $[3,4]$. The estimated overall global premature birth rate is $11.1 \%$ [5], and with an approximate rate of $11.8 \%$ [6], Brazil is in the top 10 countries with the highest rates $[1,2]$.

Studies have associated prematurity with low serum levels of vitamin D during gestation, which is a period of risk for vitamin D deficiency and insufficiency. Vitamin D can be obtained in several ways: by endogenous synthesis in the skin driven by exposure to ultraviolet $B$ rays

(c) The Author(s). 2019 Open Access This article is distributed under the terms of the Creative Commons Attribution 4.0 International License (http://creativecommons.org/licenses/by/4.0/), which permits unrestricted use, distribution, and 
in sunlight, during which 7-dehydrocholesterol is converted to cholecalciferol (vitamin D3) [7]; and from dietary sources such as fatty fish, which contain cholecalciferol [8], and plants and fungi containing ergocalciferol (vitamin D2) [9]. Both vitamin D2 and vitamin D3 undergo two hydroxylation reactions to become active: the first in the liver by 25 -hydroxylase, which produces $25(\mathrm{OH}) \mathrm{D}$ (the circulating form); and the second in the kidneys by $1 \alpha$-hydroxylase, which produces 1 , $25(\mathrm{OH}) 2 \mathrm{D}$ (the metabolically active form) [10].

An adequate level of vitamin D 25(OH) D is above 30 $\mathrm{ng} / \mathrm{mL}(75 \mathrm{nmol} / \mathrm{L}) ; 21-29 \mathrm{ng} / \mathrm{mL}(51-74 \mathrm{nmol} / \mathrm{L})$ is insufficient, and below $20 \mathrm{ng} / \mathrm{mL}$ ( $50 \mathrm{nmol} / \mathrm{L}$ ) is low [11]. The global mean of vitamin D deficiency is $29.8 \%$ and the global mean of insufficiency during gestation is 87.0\%. Vitamin D deficiency during pregnancy is associated with increased risk of gestational diabetes, preeclampsia, fetal growth restriction, bacterial vaginosis, caesarean section, and prematurity [12]. Vitamin D deficiency is also common among infants in several countries; prevalence ranges from 50 to $70 \%$ in the United States [13], and it is approximately $60.5 \%$ in Brazil [14].

Most of the biological activities attributable to vitamin D are mediated by its receptor (VDR), which is encoded by the VDR gene (vitamin $D$ receptor; Gene ID 7421; MIM 601769) with a chromosomal locus of $12 \mathrm{q} 13.11$. It is a member of the steroid hormone receptor family that mediates the action of vitamin D by regulating the transcription of multiple genes [15]. Alterations in the $V D R$ gene can lead to important defects in gene activation that can affect calcium metabolism [10], cell proliferation [8, 16], and immune function [8]. The most studied $V D R$ gene single nucleotide variation (SNV) related to clinical outcomes are ApaI, BsmI, FokI, and TaqI [17-22].

Studies have produced conflicting results regarding the association between $V D R$ gene variants and prematurity [17-22]. Different allelic frequencies among the populations arise from different genetic ancestries, so the racial origins of the studied population may be responsible for the divergent results. Hence, Brazilian population shows contributions from three main parental groups: Amerindian, European, and African [23, 24], this heterogeneity can produce different allele frequencies from those presented by non-mixed populations.

In the present study, we investigated the possible influence of vitamin D plasma concentrations and the frequency of VDR gene TaqI, BsmI, ApaI, and FokI variants in mothers and their preterm and full-term newborns.

\section{Methods}

\section{Subjects}

We carried out a case-control study involving 132 mothers in puerperia and their newborns at the Hospital
Municipal Universitário de São Bernardo do Campo of the Faculdade de Medicina do ABC, Santo André, Brazil, who were recruited from September 2016 to December 2017.

The participants were divided into 2 groups: a case group comprising 40 pairs of mothers and their preterm newborns (PTNs); and a control group comprising 92 pairs of mothers and their full-term newborns (FTNs). Newborns that had gestated for less than 32 weeks and/ or had birth weights of less than $1500 \mathrm{~g}$ were included in the case group, and the control group contained newborns that had gestated for 37 to $416 / 7$ weeks. The classification of birth weight and gestational age was in accordance with the INTERGROWTH-21 consortium $[25,26]$. The exclusion criteria were: newborns with major malformations, genetic syndromes, and severe neonatal anoxia, and cases where it was impossible to measure vitamin D levels.

The data and sample collection were only performed after all participants had signed written consent to participate, approved by the ethics committee of the Faculdade de Medicina do ABC (CAAE: 54166216.5.0000.0082).

\section{Sample collection}

At the time of delivery, $10 \mathrm{~mL}$ of peripheral blood was collected from each mother by peripheral venipuncture in a tube containing a clot-separating gel and a tube containing ethylenediaminetetraacetic acid (EDTA). We collected $10 \mathrm{~mL}$ of umbilical cord blood from the PTNs at the time of delivery in a tube containing clotseparating gel and exfoliated cells from the oral mucosa after discharge. After collection, the tubes for the biochemical dosages were centrifuged $(1500 \mathrm{rpm}$ for 10 $\mathrm{min}$ ), and the plasma was aliquoted into microtubes and frozen at $-20^{\circ} \mathrm{C}$. The tube for DNA extraction was stored in a refrigerator at $8^{\circ} \mathrm{C}$ until required.

\section{Vitamin D}

We determined the levels of $25(\mathrm{OH}) \mathrm{D}$ by electrochemiluminescence using an Elecsys ${ }^{\circ}$ Vitamin D Total II kit (Roche, Basel, Switzerland). The requisite level of $25(\mathrm{OH}) \mathrm{D}$ is considered to be $>30 \mathrm{ng} / \mathrm{mL}$ [27].

\section{Genotyping}

We extracted DNA from each mother's peripheral blood lymphocytes using the salt-out method described by Lahiri and Nurnberger [28], and from the oral mucosal cells of newborns using an ORAcollect ${ }^{\circ}$ DNA OCR-10 kit (Genotek, Ontario, Canada) according to the manufacturer's instructions. The VDR genotypes of the TaqI (NC_000012.11:g.48238757A > G, rs731236), BsmI (NC_ 000012.11:g.48239835C $>\mathrm{T}$, rs1544410), ApaI ( $\mathrm{NC}_{-}$ 000012.11:g.48238837C > A, rs7975232), and FokI (NC_ 000012.11:g.48272895A > G, rs2228570) variants were 
identified by real-time PCR using TaqMan probes from Thermo Fisher Scientific (Waltham, Massachusetts, USA) according to the manufacturer's instructions, and a StepOne ${ }^{\text {rm }}$ Real-Time PCR System (Applied Biosystems $^{\mathrm{Tm}}$, Thermo Fisher Scientific ${ }^{\circ}$, Massachusetts, USA).

Single Nucleotide Variants were described according to Human Genome Variation Society (HGVS) guidelines (http://www.hgvs.org/content/guidelines) [29].

\section{Statistical analyses}

We performed the statistical analyses using Stata ${ }^{\circ}$ software (SE 11.0) for Windows. The data were described by absolute and relative frequencies, and by assessing central tendency and dispersion. We used the Shapiro-Wilk test to determine the data's normality. The qualitative variables were analyzed using the chi-square test, the Mann-Whitney test was used for the continuous variables without normal distributions, and Student's $t$ test was used for quantitative variables with normal distributions.

The chi-square test was also used to detect differences in allele and genotype frequencies of the $V D R$ variants between groups, and to estimate the Hardy-Weinberg equilibrium (HWE). The associations between the combined alleles of $V D R$ variants and the prematurity risk were evaluated using Haploview software version 4.1, available at http://www.hapmap.org.

Odds ratios (ORs) and confidence intervals (CIs) were used to measure the strength of the associations among the frequencies of $V D R$ genotypes, vitamin D concentration, and prematurity. All $P$-values were two-tailed, and 95\% CIs were calculated. The associations between genotypes of the VDR gene variants, isolated and adjusted according to vitamin $\mathrm{D}$ concentrations, with prematurity risk were calculated by logistic regression. $P$-values < 0.05 were considered statistically significant.

\section{Results}

The data relating to the mothers and PTN and FTN newborns are shown in Table 1. The mean age of the mothers who experienced preterm births was $26.4 \pm$ 7.1 years, compared to $25.8 \pm 6.9$ years for mothers who experienced full-term births. The mean pregestational body mass index for the mothers of PTNs was $27.2 \pm 4.9 \mathrm{~kg} / \mathrm{m}^{2}$, compared to $26.2 \pm 5.7 \mathrm{~kg} / \mathrm{m}^{2}$ for the mothers of FTNs. Two mothers (5.0\%) in the case group and three $(3.3 \%)$ mothers in the control group received $25(\mathrm{OH})$ D supplementation during gestation $(P=0.631)$. Considering pregnancy diseases, specific hypertension disease in pregnancy was found in $45.0 \%$ of mothers in the case group and $13.0 \%$ in the control group $(P<0.001)$; however, gestational diabetes mellitus $(5.0 \%$ versus $2.2 \%)$ and urinary tract infection $(22.5$ and $33.7 \%)$ were not statistically different between groups. Only $10.0 \%$ of mothers in the case group reported regular solar exposure compared with $66.3 \%$ of mother of the control group $(P<0.001)$.

\section{Vitamin D}

The plasma concentrations of $25(\mathrm{OH}) \mathrm{D}$ in the mothers and newborns are shown in Table 1. Samples were collected in the spring and summer seasons for $88.6 \%$ of the cases, including $100.0 \%$ of the full-term group $(25(\mathrm{OH}) \mathrm{D}$ mean $31.7 \pm 11.7 \mathrm{ng} / \mathrm{mL})$ and $62.5 \%$ of the premature group $(25(\mathrm{OH})$ D mean $24.5 \pm 12.9 \mathrm{ng} / \mathrm{mL})$, whereas $11.4 \%$ were collected in the autumn and winter seasons, comprising $37.5 \%(25(\mathrm{OH}) \mathrm{D}$ mean $31.2 \pm 13.6$ $\mathrm{ng} / \mathrm{mL}$ ) of the preterm group.

With regard to the plasma concentrations of $25(\mathrm{OH})$ $\mathrm{D}$ in the mothers, 7 (17.5\%) of the PTN mothers and 35 (40.7\%) of the FTN mothers presented with sufficient vitamin levels ( $\geq 30 \mathrm{ng} / \mathrm{mL}) ; 14(35.0 \%)$ of the PTN mothers and $23(26.7 \%)$ of the FTN mothers presented with insufficient levels $(21-29 \mathrm{ng} / \mathrm{mL})$; and $19(47.5 \%)$ of the PTN mothers and $28(32.6 \%)$ of the FTN mothers had deficient plasma concentrations $(\leq 20 \mathrm{ng} / \mathrm{mL})(P=$ 0.036).

With regard to the plasma concentrations of $25(\mathrm{OH})$ $\mathrm{D}$ in the newborns, $16(42.1 \%)$ of the PTNs and 47 (56.0\%) of the FTNs had sufficient 25(OH) D levels; 9 (23.7\%) of the PTNs and 24 (28.6\%) of the FTNs had insufficient levels; and $13(34.2 \%)$ of the PTNs and 13 $(15.4 \%)$ of the FTNs were deficient $(P=0.064)$.

\section{VDR gene variants}

With regard to the $V D R$ variants, the genotype and allele frequencies of the TaqI, BsmI, ApaI, and FokI variants in the PTN and FTN mothers and newborns are shown in Table 2. The frequencies of the studied variant genotypes were in HWE, except for the BsmI SNV in the mothers and their PTNs.

With regard to the mothers, the frequencies of the GG variant genotype of TaqI SNV (22.8 and 7.5\% for the full-term and preterm groups, respectively) and the CT heterozygous genotype of BsmI SNV (38.0 and 0\%) were significantly higher in the full-term group than in the preterm group, whereas the TT variant homozygous genotype of BsmI SNV was significantly more frequent in the PTN mothers (62.5 and 25.0\%). We observed similar genotype frequencies with regard to the BsmI SNV in the newborns. The frequency of the CT heterozygous genotype was significantly higher in the FTNs (40.2 and 2.5\%), whereas the TT variant homozygous genotype was more frequent in the PTNs (62.5 and 18.5\%). The AA variant homozygous genotypes of ApaI SNV was also significantly more frequent among the PTNs mother (35 and 13\%) and preterm newborns (45.0 and 15.2\%). The GG genotype of FokI 
Table 1 Characteristics of mothers and their preterm and full-term newborns

\begin{tabular}{|c|c|c|c|}
\hline Variables & Preterm & Full-term & $P$-value \\
\hline \multicolumn{4}{|l|}{ Mothers } \\
\hline Age (years) $(n=129)$ & $26.4 \pm 7.1$ & $25.8 \pm 6.9$ & $0.615^{1}$ \\
\hline Pre-gestational body mass index $\left(\mathrm{kg} / \mathrm{m}^{2}\right)(n=108)$ & $27.2 \pm 4.9$ & $26.2 \pm 5.7$ & $0.458^{1}$ \\
\hline \multicolumn{4}{|l|}{ Education $(n=128)$} \\
\hline $0-4$ years & $2(5.3 \%)$ & $2(2.2 \%)$ & \multirow[t]{3}{*}{$0.263^{2}$} \\
\hline $4-8$ years & $30(78.9 \%)$ & $63(70.0 \%)$ & \\
\hline $8-12$ years & $6(15.8 \%)$ & $25(27.8 \%)$ & \\
\hline Alcoholism $(n=132)$ & $2(5.0 \%)$ & $5(5.4 \%)$ & $0.918^{2}$ \\
\hline Smoking $(n=132)$ & $5(12.5 \%)$ & $10(10.9 \%)$ & $0.786^{2}$ \\
\hline \multicolumn{4}{|l|}{ Type of birth $(n=132)$} \\
\hline Vaginal & $12(30.0 \%)$ & $40(43.5 \%)$ & \multirow[t]{3}{*}{$0.191^{2}$} \\
\hline cesarean section & $28(70.0 \%)$ & $50(54.3 \%)$ & \\
\hline Fórceps & $0(0.0 \%)$ & $2(2.2 \%)$ & \\
\hline \multicolumn{4}{|l|}{ Pregnancy diseases $(n=132)$} \\
\hline Specific hypertension disease in pregnancy & $18(45.0 \%)$ & $12(13.0 \%)$ & $<0.001^{2}$ \\
\hline Gestational diabetes mellitus & $2(5.0 \%)$ & $2(2.2 \%)$ & $0.384^{2}$ \\
\hline Urinary tract infection & $9(22.5 \%)$ & $31(33.7 \%)$ & $0.198^{2}$ \\
\hline Pregnancies' number ( $n=132)$ & $1.95 \pm 1.15$ & $2.2 \pm 1.3$ & $0.243^{1}$ \\
\hline Vitamin D Supplementation $(n=132)$ & $2(5.0 \%)$ & $3(3.3 \%)$ & $0.631^{2}$ \\
\hline Folic acid (yes) ( $n=132)$ & $32(80.0 \%)$ & $81(88.0 \%)$ & $0.226^{2}$ \\
\hline Iron (yes) $(n=132)$ & 33 (82.5\%) & 78 (84.8\%) & $0.742^{2}$ \\
\hline Photo protection frequently $(n=132)$ & $8(20.0 \%)$ & $14(15.2 \%)$ & $0.498^{2}$ \\
\hline Regular solar exposure $(n=132)$ & $4(10.0 \%)$ & $61(66.3 \%)$ & $<0.001^{2}$ \\
\hline Vitamin $\mathrm{D}(\mathrm{ng} / \mathrm{ml})(n=126)$ & $20.8 \pm 11.8$ & $26.5 \pm 9.7$ & $0.004^{1}$ \\
\hline Sufficent levels (> 30 ng/mL) & $7(17.5 \%)$ & $35(40.7 \%)$ & \multirow[t]{3}{*}{$0.036^{1}$} \\
\hline Insufficient levels (21-29 ng/mL) & $14(35.0 \%)$ & $23(26.7 \%)$ & \\
\hline Deficient levels ( $\leq 20$ ng/mL) & $19(47.5 \%)$ & $28(32.6 \%)$ & \\
\hline \multicolumn{4}{|l|}{ Newborns } \\
\hline Gestational age (weeks) $(n=131)$ & $29.6 \pm 2.5$ & $39.1 \pm 1.8$ & $<0.001^{1}$ \\
\hline Birth weight (g) $(n=131)$ & $1239 \pm 336$ & $3285 \pm 558$ & $<0.001^{1}$ \\
\hline Birth length $(\mathrm{cm})(n=94)$ & $38.7 \pm 2.8$ & $48.3 \pm 3.1$ & $<0.001^{1}$ \\
\hline Birth cephalic perimeter $(\mathrm{cm})(n=112)$ & $26.9 \pm 2.1$ & $34.3 \pm 1.7$ & $<0.001^{1}$ \\
\hline \multicolumn{4}{|l|}{ Gender $(n=130)$} \\
\hline Male & $17(43.6 \%)$ & $51(56.0 \%)$ & \multirow[t]{2}{*}{$0.193^{2}$} \\
\hline Female & $22(56.4 \%)$ & $40(44.0 \%)$ & \\
\hline \multicolumn{4}{|l|}{ Gestational Age classification ${ }^{a}(n=130)$} \\
\hline Small for gestational age & $7(17.5 \%)$ & $4(4.4 \%)$ & \multirow[t]{3}{*}{$0.037^{1}$} \\
\hline Adequate for gestational age & 29 (72.5\%) & $71(78.9 \%)$ & \\
\hline Large for gestational age & $4(10.0 \%)$ & $15(16.7 \%)$ & \\
\hline Vitamin $\mathrm{D}(\mathrm{ng} / \mathrm{ml})(n=130)$ & $27.2 \pm 13.4$ & $31.7 \pm 11.7$ & $0.056^{1}$ \\
\hline Sufficent levels (> 30 ng/mL) & $16(42.1 \%)$ & $47(56.0 \%)$ & \multirow[t]{3}{*}{0.064} \\
\hline Insufficient levels (21-29 ng/mL) & $9(23.7 \%)$ & $24(28.6 \%)$ & \\
\hline Deficient levels ( $\leq 20$ ng/mL) & $13(34.2 \%)$ & $13(15.4 \%)$ & \\
\hline
\end{tabular}

${ }^{1} \mathrm{~T}$ test; ${ }^{2}$ Chi-square test 
Table 2 The genotype and allele frequencies of the Taql, Bsml, Apal, and Fokl variants of the VDR gene in preterm and full-term mothers and newborns

\begin{tabular}{|c|c|c|c|c|c|c|c|c|c|c|c|}
\hline \multirow[t]{2}{*}{ VDR SNVs } & \multirow[t]{2}{*}{ Population } & \multirow[t]{2}{*}{ N } & \multicolumn{5}{|c|}{ Genotypes } & \multirow[t]{2}{*}{ HWE } & \multicolumn{3}{|l|}{ Alleles } \\
\hline & & & n (\%) & n (\%) & $p$ & n (\%) & $p$ & & n (\%) & n (\%) & $p$ \\
\hline \multicolumn{12}{|l|}{ Mothers } \\
\hline & & & $A A$ & AG & & GG & & & A & G & \\
\hline \multirow[t]{3}{*}{ Taql/A $>$ G } & Preterm & 40 & $19(47.5)$ & $18(45.0)$ & 0.105 & $3(7.5)$ & 0.009 & 0.903 & $56(70.0)$ & $24(30.0)$ & 0.007 \\
\hline & Full-term & 92 & $25(27.2)$ & $46(50.0)$ & & $21(22.8)$ & & 1.0 & $96(52.2)$ & 88 (47.8) & \\
\hline & & & CC & $\mathrm{CT}$ & & $\mathrm{TT}$ & & & $C$ & $\mathrm{~T}$ & \\
\hline \multirow[t]{3}{*}{$\mathrm{Bsml} / \mathrm{C}>\mathrm{T}$} & Preterm & 40 & $15(37.5)$ & 0 & 0.001 & $25(62.5)$ & 0.031 & $<0.001$ & $30(37.5)$ & $50(62.5)$ & 0.005 \\
\hline & Full-term & 92 & $34(37.0)$ & $35(38.0)$ & & $23(25.0)$ & & 0.260 & $103(56.0)$ & 81 (44.0) & \\
\hline & & & $\mathrm{CC}$ & $C A$ & & $A A$ & & & $C$ & A & \\
\hline \multirow[t]{3}{*}{ Apal/C > A } & Preterm & 40 & $5(12.5)$ & $21(52.5)$ & 0.067 & $14(35.0)$ & $<0.001$ & 0.799 & 31 (38.8) & 49 (61.2) & 0.001 \\
\hline & Full-term & 92 & 31 (33.7) & 49 (53.3) & & $12(13.0)$ & & 0.558 & $111(60.3)$ & 73 (39.7) & \\
\hline & & & AA & AG & & GG & & & A & G & \\
\hline \multirow[t]{2}{*}{ Fokl/A $>G$} & Preterm & 40 & $4(10.0)$ & $18(45.0)$ & 0.284 & $18(45.0)$ & 0.323 & 0.987 & $26(32.5)$ & $54(67.5)$ & 0.436 \\
\hline & Full-term & 92 & $16(17.4)$ & $37(40.2)$ & & 39 (42.4) & & 0.397 & 69 (37.5) & $115(62.5)$ & \\
\hline \multicolumn{12}{|l|}{ Newborns } \\
\hline & & & $A A$ & AG & & GG & & & A & G & \\
\hline \multirow[t]{3}{*}{ Taql/A $>$ G } & Preterm & 40 & $17(42.5)$ & $18(45.0)$ & 0.788 & $5(12.5)$ & 0.447 & 1.0 & $52(65.0)$ & $28(35.0)$ & 0.705 \\
\hline & Full-term & 92 & 39 (42.4) & $46(50.0)$ & & $7(7.6)$ & & 0.419 & $124(67.5)$ & $60(32.5)$ & \\
\hline & & & $\mathrm{CC}$ & $\mathrm{CT}$ & & $\mathrm{TT}$ & & & $C$ & $\mathrm{~T}$ & \\
\hline \multirow[t]{3}{*}{$\mathrm{Bsml} / \mathrm{C}>\mathrm{T}$} & Preterm & 40 & $14(35.0)$ & $1(2.5)$ & 0.002 & $25(62.5)$ & 0.001 & $<0.001$ & 29 (36.3) & $51(63.7)$ & $<0.001$ \\
\hline & Full-term & 92 & $38(41.3)$ & $37(40.2)$ & & $17(18.5)$ & & 0.348 & $113(61.4)$ & 71 (38.6) & \\
\hline & & & CC & $C A$ & & $A A$ & & & $\mathrm{C}$ & $A$ & \\
\hline \multirow[t]{3}{*}{ Apal/C > A } & Preterm & 40 & $6(15.0)$ & $16(40.0)$ & 0.839 & $18(45.0)$ & 0.004 & 0.900 & $28(35.0)$ & $52(65.0)$ & 0.002 \\
\hline & Full-term & 92 & $23(25.0)$ & $55(59.8)$ & & $14(15.2)$ & & 0.139 & $101(54.9)$ & $83(45.1)$ & \\
\hline & & & $A A$ & AG & & GG & & & A & G & \\
\hline \multirow[t]{2}{*}{ Fokl/A $>G$} & Preterm & 40 & $1(2.5)$ & $19(47.5)$ & 0.109 & $20(50.0)$ & 0.037 & 0.358 & $21(26.3)$ & $59(73.7)$ & 0.053 \\
\hline & Full-term & 92 & $12(13.0)$ & $47(51.1)$ & & $33(35.9)$ & & 0.757 & 71 (38.6) & $113(61.4)$ & \\
\hline
\end{tabular}

SNV Single Nucleotide Variant described according to HGVS nomenclature, OR Odds Ratio;

$\mathrm{Cl}$ Confidence Interval, HWE Hardy-Weinberg Equilibrium

${ }^{*}$ Chi-square test. Wild genotype as reference. $P<0.05$

SNV (50.0 and 35.9\%) were also significantly more frequent among the PTNs.

The associations of the VDR gene TaqI, ApaI, and FokI combined allele in the mothers and their PTNs and FTNs are shown in Table 3. Because the BsmI variant was not in HWE in the mothers and PTNs, we did not consider this SNV in the haplotype analysis. The AAG (TaqI/A-ApaI/ A-FokI/G) (33.5 and 20.4\% in the PTN and FTN groups, respectively) and GCA (TaqI/G-ApaI/G-FokI/A) (2.7 and $1.1 \%)$ haplotypes were more frequent among the PTN mothers, whereas the GCG (TaqI/G-ApaI/C-FokI/G) haplotype was more frequent in the FTN mothers (22.5 and 5.8\%). Among the newborns, the GAG (TaqI/G-ApaI/ A-FokI/G) (18.5 and 5.6\%) haplotypes was more frequent in the PTNs, whereas the GCA (13.5 and 4.0\%) haplotype was more frequent in the FTNs.
Genotypes of VDR variants and 25(OH) D concentration The concentrations of $25(\mathrm{OH}) \mathrm{D}$ in relation to the genotypes of $V D R$ gene variants in the mothers and newborns are presented in Table 4. The PTN mothers with the AG genotype of the TaqI SNV, the AA genotype of the ApaI SNV, and the AG genotype of the FokI SNV had significantly lower $25(\mathrm{OH})$ D levels than the FTN mothers. With regard to PTNs, the carriers of the GG genotype of the FokI SNV had significantly lower $25(\mathrm{OH})$ D levels than the FTN group.

\section{Prematurity risk}

The risks of prematurity in relation to the genotypes of $V D R$ variants associated with $25(\mathrm{OH}) \mathrm{D}$ deficiency in the mothers are shown in Table 5. Regardless of their association with $25(\mathrm{OH})$ D deficiency, the variant 
Table 3 Haplotype analysis of Taql, Apal, and Fokl variants of the VDR gene in mothers and their preterm and full-term newborns

\begin{tabular}{|c|c|c|c|c|c|c|}
\hline \multirow[t]{2}{*}{ Population } & \multicolumn{3}{|l|}{ Haplotypes } & \multirow{2}{*}{$\begin{array}{l}\text { Preterm } \\
\text { Frequency } \\
(\%)\end{array}$} & \multirow{2}{*}{$\begin{array}{l}\text { Full-term } \\
\text { Frequency } \\
(\%)\end{array}$} & \multirow[t]{2}{*}{$P^{*}$} \\
\hline & Taql $(A>G)$ & Apal $(C>A)$ & $\begin{array}{l}\text { Fokl } \\
(A>G)\end{array}$ & & & \\
\hline \multicolumn{7}{|l|}{ Mothers } \\
\hline & A & A & G & 33.5 & 20.4 & 0.022 \\
\hline & G & $C$ & G & 5.8 & 22.5 & 0.001 \\
\hline & A & $C$ & A & 14.5 & 14.8 & 0.947 \\
\hline & A & $C$ & G & 15.8 & 12.0 & 0.395 \\
\hline & G & A & G & 12.5 & 7.7 & 0.213 \\
\hline & G & $C$ & A & 2.7 & 1.1 & 0.025 \\
\hline & G & A & A & 9.1 & 6.6 & 0.477 \\
\hline & A & A & A & 6.2 & 5.0 & 0.687 \\
\hline \multicolumn{7}{|l|}{ Newborns } \\
\hline & A & A & G & 34.6 & 26.7 & 0.188 \\
\hline & A & $C$ & G & 17.3 & 20.1 & 0.595 \\
\hline & A & C & A & 10.4 & 12.2 & 0.670 \\
\hline & G & $C$ & A & 4.0 & 13.5 & 0.021 \\
\hline & G & A & G & 18.5 & 5.6 & 0.001 \\
\hline & G & $C$ & G & 3.3 & 9.1 & 0.099 \\
\hline & A & A & A & 2.7 & 8.4 & 0.085 \\
\hline & G & $A$ & $A$ & 9.2 & 4.4 & 0.131 \\
\hline
\end{tabular}

*Software Haploview version 4.1. $P<0.05$

genotypes of the BsmI/TT and ApaI/AA SNVs were associated with the increased risk of prematurity. Mothers with the TT variant genotype of the BsmI SNV, and with $25(\mathrm{OH}) \mathrm{D}$ deficiency, had a 2.36-fold increased chance of preterm birth, whereas carriers of the variant genotype AA of the ApaI SNV had an increased risk of prematurity, i.e., 7.99-fold higher. The carriers of the GG genotype of the TaqI SNV had a lower risk of preterm birth, even when associated with $25(\mathrm{OH}) \mathrm{D}$ deficiency.

\section{Discussion}

During gestation, the mother is the fetus' only source of vitamin $\mathrm{D}$, which is transmitted across the placenta [30]. The levels of vitamin $\mathrm{D}$ in the mother are directly related to those in the fetus, and vitamin D deficiency has been associated with an increased risk of certain childhood diseases, such as rickets, infectious diseases, noncommunicable chronic diseases, obesity, and asthma [13]. The reduction in the level of albumin and the increase in the hepatic production of vitamin D-binding protein (DBP) during pregnancy alter maternal vitamin $\mathrm{D}$ metabolism. This reduces the availability of free vitamin $\mathrm{D}$ and increases the conversion of $25(\mathrm{OH}) \mathrm{D}$ to 1 , $25(\mathrm{OH}) 2 \mathrm{D} 3$ through the placenta, which is the main extra-renal site of this conversion owing to the increased activity of $1 \alpha$-hydroxylase [30]. Moreover, the late transfer of vitamin $\mathrm{D}$ to the fetus may be impaired in preterm birth, which has prompted various investigations of serum vitamin D levels in pregnant women [31, 32].

A meta-analysis including 10,098 patients from 10 studies found an increased risk of preterm birth for pregnant women with vitamin D deficiency $(<20 \mathrm{ng} / \mathrm{mL}$; $\mathrm{OR}=1.29 ; 95 \% \mathrm{IC}=1.16-1.45)$ [31]. A meta-analysis performed by Zhou et al. (2017) [33] including 6 randomized controlled trials and 18 observational studies, the increased risk of prematurity was associated to deficiency $(\mathrm{OR}=1.25 ; 95 \% \mathrm{IC}=1.13-1.38)$ more than maternal vitamin $\mathrm{D}$ insufficiency $(\mathrm{OR}=1.09 ; 95 \% \mathrm{IC}=$ 0.89-1.35). Recently, the association between maternal vitamin D deficiency and preterm birth was evaluated in a study by Woo et al. [34] comprising studies from 2012 to 2018, being non conclusive despite analysis of research indicates that vitamin $\mathrm{D}$ deficiency is related to an increased risk for preterm birth [34].

The evidence suggests that preterm labor is a heterogeneous condition with many triggering and precipitating factors, especially infections and inflammatory causes [35]. 1,25(OH)2D promotes cytokine inhibition and the expression of potent antimicrobial peptides in various immune cells, such as macrophages and dendritic cells, and acts on placental tissue by modulating anti-inflammatory effects [31].

Preeclampsia is a risk factor for premature birth whose only treatment is birth [36, 37]. A large body of 
Table 4 The relationships between the concentrations of $25(\mathrm{OH}) \mathrm{D}$ and the genotypes of the VDR gene variants in mothers and their preterm and full-term newborns

\begin{tabular}{|c|c|c|c|c|c|c|c|c|}
\hline \multirow[t]{2}{*}{ VDR SNVs } & \multirow[t]{2}{*}{ Genotypes } & \multirow[t]{2}{*}{$\mathrm{N}$} & \multicolumn{2}{|c|}{ Preterm } & \multirow[t]{2}{*}{$\mathrm{N}$} & \multicolumn{2}{|c|}{ Full-term } & \multirow[t]{2}{*}{$P * *$} \\
\hline & & & $\%$ & Vitamin $D^{*}(\mathrm{ng} / \mathrm{mL})$ & & $\%$ & Vitamin $D^{*}(\mathrm{ng} / \mathrm{mL})$ & \\
\hline \multicolumn{9}{|c|}{ Mothers $(n=132)$} \\
\hline \multirow[t]{3}{*}{$\mathrm{Taq} / / \mathrm{A}>\mathrm{G}$} & AA & 19 & 47.5 & $20.90(16.18 ; 25.62)$ & 25 & 27.2 & 24.74 (20.025 28.09) & 0.291 \\
\hline & $A G$ & 18 & 45.0 & $20.83(13.79 ; 27.87)$ & 46 & 50.0 & 28.05 (25.010; 30.96) & 0.023 \\
\hline & GG & 3 & 7.5 & $19.90(-10.42 ; 50.22)$ & 21 & 22.8 & $25.24(21.30 ; 29.17)$ & 0.348 \\
\hline \multirow[t]{3}{*}{$\mathrm{Bsml} / \mathrm{C}>\mathrm{T}$} & $\mathrm{CC}$ & 15 & 37.5 & $21.54(16.17 ; 26.91)$ & 34 & 37.0 & $26.48(22.77 ; 30.19)$ & 0.131 \\
\hline & $\mathrm{CT}$ & 0 & 0.0 & - & 35 & 38.0 & $28.24(24.75 ; 31.73)$ & $* * *$ \\
\hline & $\pi$ & 25 & 62.5 & $20.35(14.95 ; 25.75)$ & 23 & 25.0 & $23.93(21.00 ; 26.87)$ & 0.245 \\
\hline \multirow[t]{3}{*}{ Apal/C > A } & $\mathrm{CC}$ & 5 & 12.5 & $20.28(14.26 ; 26.30)$ & 31 & 33.7 & $24.07(20.71 ; 27.43)$ & 0.375 \\
\hline & CA & 21 & 52.5 & $23.71(17.47 ;$ 29.96) & 49 & 53.3 & 28.04 (25.27 30. 80) & 0.136 \\
\hline & $\mathrm{AA}$ & 14 & 35.0 & $16.60(11.17 ; 22.04)$ & 12 & 13.0 & $26.60(19.80 ; 33.40)$ & 0.018 \\
\hline \multirow[t]{3}{*}{ Fokl/A $>G$} & AA & 4 & 10.0 & $20.71(-9.45 ; 50.88)$ & 16 & 17.4 & $26.61(22.08 ; 31.13)$ & 0.348 \\
\hline & $A G$ & 18 & 45.0 & $20.26(14.97 ; 25.55)$ & 37 & 40.2 & $26.96(23.77 ; 30.17)$ & 0.022 \\
\hline & GG & 18 & 45.0 & $21.34(15.41 ; 27.28)$ & 39 & 42.4 & $26.04(22,68 ; 29.40)$ & 0.136 \\
\hline \multicolumn{9}{|c|}{ Newborns $(n=38)$} \\
\hline \multirow[t]{3}{*}{ Taql/A $>$ G } & AA & 18 & 47.4 & 27.95 (21.13 34.78) & 39 & 42.4 & $30.436(27.510 ; 33.76$ & 0.451 \\
\hline & $A G$ & 16 & 42.1 & $27.64(20.14 ; 35.15)$ & 46 & 50.0 & $32.76(28.93 ; 36.59)$ & 0.186 \\
\hline & GG & 4 & 10.5 & $21.58(5.42 ; 37.74)$ & 7 & 7.6 & $31.60(20.60 ; 42.59)$ & 0.192 \\
\hline \multirow[t]{3}{*}{$\mathrm{Bsml} / \mathrm{C}>\mathrm{T}$} & $C C$ & 14 & 36.8 & $28.68(20.09 ; 37.27)$ & 38 & 41.3 & $31.78(27.85 ; 35.72)$ & 0.441 \\
\hline & $\mathrm{CT}$ & 1 & 2.6 & 39.62 & 37 & 40.2 & $33.37(42)$ & $* * *$ \\
\hline & $\pi$ & 23 & 60.6 & $25.68(20.21 ; 31.15)$ & 17 & 18.5 & $27.80(22.87 ; 32.73)$ & 0.566 \\
\hline \multirow[t]{3}{*}{ Apal/C > A } & CC & 6 & 15.7 & $26.78(15.15 ; 38.40)$ & 23 & 25.0 & $33.31(26.88 ; 39.74)$ & 0.326 \\
\hline & CA & 15 & 39.5 & $32.04(23.34 ; 40.75)$ & 55 & 59.8 & $31.74(28.70 ; 34.79)$ & 0.934 \\
\hline & $\mathrm{AA}$ & 17 & 44.8 & $22.97(17.37 ; 28.57)$ & 14 & 15.2 & $28.79(24.99 ; 32.60)$ & 0.090 \\
\hline \multirow[t]{3}{*}{ Fokl/A $>G$} & $\mathrm{AA}$ & 1 & 2.6 & 37.66 & 12 & 13.0 & $34.17(25.64 ; 42.70)$ & $* * *$ \\
\hline & $A G$ & 19 & 50.0 & $30.00(23.72 ; 36.27)$ & 47 & 51.1 & $30.76(27.75 ; 33.77)$ & 0.801 \\
\hline & GG & 18 & 47.4 & $23.57(18.87 ; 30.26)$ & 33 & 35.9 & $32.10(27.44 ; 36.76)$ & 0.032 \\
\hline
\end{tabular}

$\mathrm{N}$ : Sample number. * Mean concentrations of $25(\mathrm{OH}) \mathrm{D}$ (confidence interval). ${ }^{* *}$-test. ${ }^{* * *}$ Not possible calculated due sample size. $P<0.05$

evidence indicates that increased inflammatory response is a feature of systemic vascular dysfunction in this disorder, although its cause is not completely known [38, 39]. Due to vitamin D anti-inflammatory effects, it may play a role in preeclampsia prevention [34, 40-42]. A recent study [43] pointed that downregulation of VDR expression and vitamin D deficiency may contribute to phenotypic changes of inflammatory patterns in maternal vasculature in preeclampsia. Otherwise, the VDR FokI variant was associated with decreased risk of preeclampsia in the dominant model in Iranian population [44].

Despite the evidence of an association between vitamin $\mathrm{D}$ deficiency and preterm birth and preeclampsia, data on the effect of vitamin D supplementation on preterm birth have not been consistent, probably due to the heterogeneity of studies regarding the differences in assay methodologies, definitions of vitamin D deficiency, timing of supplementation, and dose of supplementation [34]. A recent Cochrane review [39] showed evidence from 3725 pregnant women enrolled in 22 studies, suggesting that vitamin $\mathrm{D}$ supplementation alone during pregnancy potentially attenuates the risk of preeclampsia in comparison to placebo or no intervention. Also, it may have small or even no difference for the risk of premature birth. Other review raised evidence from nine studies involving 1916 pregnant women and suggested that the risk of preeclampsia is reduced when supplementation with vitamin $\mathrm{D}$ and calcium is performed, although may increases risk of preterm birth. Other than that, the benefits or harms of vitamin D supplementation alone or combined with calcium and other vitamins and minerals during pregnancy for mother and children remains unclear [39]. 
Table 5 The risks of prematurity in relation to the genotypes of the VDR variants, and their association with $25(\mathrm{OH}) \mathrm{D}$ deficiency in the mothers

\begin{tabular}{|c|c|c|c|c|c|c|}
\hline \multirow[t]{3}{*}{ VDR SNVS } & \multirow[t]{3}{*}{ Genotypes } & \multirow[t]{3}{*}{ Odds } & \multicolumn{4}{|l|}{ Prematurity Risk } \\
\hline & & & \multicolumn{2}{|c|}{ All mothers $(n=132)$} & \multicolumn{2}{|c|}{ Mothers with $25(\mathrm{OH}) \mathrm{D}$ deficiency $(n=47)$} \\
\hline & & & OR (CI 95\%) & $p^{*}$ & OR (IC 95\%) & $p^{* *}$ \\
\hline \multirow[t]{3}{*}{ Taql/A $>G$} & $\mathrm{AA}$ & 0.76 & Ref. & & Ref. & \\
\hline & $A G$ & 0.39 & $0.51(0.23 ; 1.16)$ & 0.107 & $0.56(0.25 ; 1.27)$ & 0.165 \\
\hline & GG & 0.14 & $0.19(0.05 ; 0.72)$ & 0.015 & $0.19(0.05 ; 0.74)$ & 0.016 \\
\hline \multirow[t]{3}{*}{$\mathrm{Bsml} / \mathrm{C}>\mathrm{T}$} & $\mathrm{CC}$ & 0.44 & Ref. & & Ref. & \\
\hline & $C T$ & 0.00 & $* * *$ & $* * *$ & $* * *$ & $* * *$ \\
\hline & $\pi$ & 1.08 & $2.46(1.07 ; 5.65)$ & 0.033 & $2.36(1.025 .47)$ & 0.044 \\
\hline \multirow[t]{3}{*}{ Apal/C $>$ A } & CC & 0.16 & Ref. & & Ref. & \\
\hline & CA & 0.43 & $2.66(0.91 ; 7.78)$ & 0.075 & $3.00(1.003 ; 8.99)$ & 0.050 \\
\hline & $\mathrm{AA}$ & 1.17 & $7.23(2.14 ; 24.48)$ & 0.001 & $7.99(2.29 ; 27.84)$ & 0.001 \\
\hline \multirow[t]{3}{*}{ Fokl $/ A>G$} & AA & 0.25 & Ref. & & Ref. & \\
\hline & $A G$ & 0.49 & $1.95(0.57 ; 6.67)$ & 0.290 & $2.01(0.58 ; 7.02)$ & 0.271 \\
\hline & GG & 0.30 & $1.85(0.54 ; 6.31)$ & 0.329 & $1.82(0.53 ; 6.33)$ & 0.344 \\
\hline
\end{tabular}

SNV Single Nucleotide Variant, OR Odds Ratio, Cl Confidence interval. Wild genotype was used as a reference for *Logistic regression

** Logistic regression adjusted for maternal vitamin D deficiency $(\leq 30 \mathrm{ng} / \mathrm{ml})$. ${ }^{* * *}$ Not possible to calculate due to sample size. $P<0.05$

Currently, some countries and international scientific organizations recommend screening in pregnant women who are at risk for vitamin D deficiency and supplementation with doses ranging from 600 to 1000 IU/day [4547]. In Brazil there are no recommendation for vitamin $\mathrm{D}$ screening and supplementation during pregnancy. WHO [48] reported a need for more evidence for recommending vitamin $\mathrm{D}$ supplementation greater than 200 units per day.

It is important to note that there are several other pregnancy and neonatal complications associated with maternal vitamin D deficiency such as increased incidence of gestational diabetes mellitus, low birth weight, and possible epigenetic effects on offspring [34].

In the present study, specific hypertension disease in pregnancy (45.0\% versus $13.0 \%$, respectively) was significantly higher in PTN mothers in relation to the FTN group; whereas gestational diabetes mellitus $(5.0 \%$ versus $2.2 \%$, respectively) and urinary tract infection (22.5\% versus $33.7 \%$, respectively) were not significantly different between PTN and FTN mothers. In addition, no difference was found considering the supplementation of vitamin D, folic acid, and iron. Only $10 \%$ of PTN mothers regularly sunbathed in relation to $66.3 \%$ in FTN mothers; however the frequency of photo protection was not different between groups $(20.0 \%$ in PTN mothers and in $15.2 \%$ of FTN mothers). Regarding the $25(\mathrm{OH}) \mathrm{D}$ levels, the present study revealed that the $25(\mathrm{OH}) \mathrm{D}$ levels in preterm mothers was significantly lower in relation to the full-term group, and there was vitamin deficiency in $47.5 \%$ of the PTN mothers. The $25(\mathrm{OH}) \mathrm{D}$ levels in preterm newborns was lower in relation to the full-term newborns, although this difference was not statistically significant. There was vitamin deficiency in $34.2 \%$ of the PTNs.

Considering the $V D R$ variants, the findings of previous studies include strong indications of no association between $V D R$ variants and the risk of prematurity (Table 6). Only six studies have associated $V D R$ gene variants with the risk of preterm birth, and no study has associated these SNVs with serum vitamin D levels.

Manzon et al. (2014) [17] investigated 33 Caucasian Jewish Israeli mothers and their preterm newborns (2435 weeks' gestation), and 98 other mothers and their FTNs. They reported that the C allele of the Fokl SNV was more frequent, and the $\mathrm{T}$ allele of the TaqI SNV was less frequent, in preterm mothers. There was no association between the genotypes of the studied variants and preterm and full-term birth. Furthermore, Cai et al. (2016) [18] investigated 57 preterm and 84 full-term Chinese mothers, and reported that the FF genotype of the Fokl SNV was associated with an increased risk of preterm birth.

Baczyńska-Strzecha et al. (2016) [19] investigated 100 Polish preterm and 99 full-term mothers. They reported that the frequencies of the individual genotypes did not differ. However, the BsmI/bb-ApaI/AA-TaqI/TT and BsmI/BB-ApaI/aa-TaqI/tt genotype combinations were significantly more frequent in the preterm group, whereas the BsmI/Bb-ApaI/AA-TaqI/Tt and BsmI/BB$\mathrm{ApaI} / \mathrm{Aa}-\mathrm{TaqI} / \mathrm{tt}$ combinations reduced the risk of preterm birth. In contrast, in a study by Rosenfeld et al. (2017) [20] - which included 146 Israeli Jewish women and their preterm newborns, and 229 other women and 
Table 6 Case-control studies associated with VDR gene variantss and the risk of prematurity

\begin{tabular}{|c|c|c|c|c|}
\hline Study & $\begin{array}{l}\text { Population } \\
\text { Origin }\end{array}$ & Groups & $\begin{array}{l}\text { VDR } \\
\text { SNVS* }\end{array}$ & Conclusions \\
\hline $\begin{array}{l}\text { Manzon et al. } \\
\text { (2013) [17] }\end{array}$ & $\begin{array}{l}\text { Israel } \\
\text { (Jewish) }\end{array}$ & $\begin{array}{l}33 \text { caucasian mothers and their PTN ( } 24-35 \text { weeks } \\
\text { gestation) } \\
98 \text { mothers and their FTN }\end{array}$ & $\begin{array}{l}\text { Taql } \\
\text { Bsml } \\
\text { Apal } \\
\text { Fokl }\end{array}$ & $\begin{array}{l}\text { The frequency of the Fokl/C allele was significantly higher } \\
\text { in mothers who had preterm births. }\end{array}$ \\
\hline $\begin{array}{l}\text { Cai et al. } \\
\text { (2016) [18] }\end{array}$ & China & $\begin{array}{l}57 \text { mothers who had PTN } \\
84 \text { mothers who had FTN }\end{array}$ & Fokl & $\begin{array}{l}\text { The Fokl/FF genotype was associated as a risk factor for } \\
\text { preterm birth. }\end{array}$ \\
\hline $\begin{array}{l}\text { Baczyńska- } \\
\text { Strzecha et al. } \\
\text { (2016) [19] }\end{array}$ & Poland & $\begin{array}{l}100 \text { caucasian mothers who had PTN (22-36.6 } \\
\text { weeks gestation) } \\
99 \text { mothers who had FTN }\end{array}$ & $\begin{array}{l}\text { Taql } \\
\text { Bsml } \\
\text { Apal }\end{array}$ & $\begin{array}{l}\text { There was no difference in the frequency of the genotypes } \\
\text { individually, but the combination of the genotypes Bsml/ } \\
\text { bb-Apal/AA-Taql/TT and Bsml/BB-Apal/aa-Taql/tt were more } \\
\text { frequent in mothers who had preterm birth. }\end{array}$ \\
\hline $\begin{array}{l}\text { Rosenfeld } \\
\text { et al. } \\
\text { (2017) [20] }\end{array}$ & $\begin{array}{l}\text { Israel } \\
\text { (Jewish) }\end{array}$ & $\begin{array}{l}146 \text { caucasian mothers and their PTN ( } 24-36 \text { weeks } \\
\text { gestation) } \\
229 \text { mothers and their FTN }\end{array}$ & $\begin{array}{l}\text { Taql } \\
\text { Bsml } \\
\text { Apal } \\
\text { Fokl }\end{array}$ & $\begin{array}{l}\text { The Apal/AA genotype was associated with an increased } \\
\text { risk of preterm birth. }\end{array}$ \\
\hline $\begin{array}{l}\text { Javorski et al. } \\
\text { (2018) [21] }\end{array}$ & $\begin{array}{l}\text { Brazil } \\
\text { (Northeast) }\end{array}$ & $\begin{array}{l}104 \text { mothers who had PTN } \\
85 \text { mothers who had FTN }\end{array}$ & Fokl & $\begin{array}{l}\text { The Fokl/ } / \text { allele was associated with a higher risk of } \\
\text { preterm birth. }\end{array}$ \\
\hline $\begin{array}{l}\text { Barchitta et al. } \\
\text { (2018) [22] }\end{array}$ & Italy & $\begin{array}{l}17 \text { mothers and their PTN }(<37 \\
\text { weeks gestation) } \\
187 \text { mothers and their FTN }\end{array}$ & Fokl & $\begin{array}{l}\text { The Fokl polymorphic genotype in mothers was associated } \\
\text { with an increased risk for preterm birth. }\end{array}$ \\
\hline This study & $\begin{array}{l}\text { Brazil } \\
\text { (Southeast) }\end{array}$ & $\begin{array}{l}40 \text { mothers and their PTN ( } 23-32 \text { weeks gestation) } \\
92 \text { mothers and their FTN }\end{array}$ & $\begin{array}{l}\text { Taql } \\
\text { Bsml } \\
\text { Apal } \\
\text { Fokl }\end{array}$ & $\begin{array}{l}\text { The Bsml/TT and Apal/AA genotype increased prematurity } \\
\text { risk, regardless of vitamin D deficiency. Preterm newborns } \\
\text { with Fokl/GG genotypes had lower serum vitamin D } \\
\text { concentrations. }\end{array}$ \\
\hline
\end{tabular}

SNV Single Nucleotide Variant, PTN preterm newborn, FTN full-term newborn, PTB preterm birth. Alleles according to HGVS nomenclature: Taql/A > G; Bsml/ C > A or $\mathrm{C}>\mathrm{G}$ or $\mathrm{C}>\mathrm{T}$; $\mathrm{Apal} / \mathrm{C}>\mathrm{A}$; and Fokl/A $>\mathrm{C}$ or $\mathrm{A}>\mathrm{G}$ or $\mathrm{A}>\mathrm{T}$

their full-term newborns - the CC homozygous genotype of the ApaI SNV was associated with premature birth.

A Brazilian study by Javorski et al. (2018) [21] - which included 104 preterm and 85 full-term mothers-revealed that the $\mathrm{T}$ allele and $\mathrm{TT}$ wild genotype of the FokI SNV were more frequent in women who had preterm births. However, an Italian study by Barchitta et al. (2018) [22] - which comprised 17 pairs of mothers and their PTNs and 187 pairs of mothers and their FTNs revealed that the Fokl variant genotype was associated with an increased risk for preterm birth.

In the present study, the TT genotype of the BsmI and AA genotype of the ApaI SNVs, and the AAG (TaqI/AApaI/A-FokI/G) and GCA (TaqI/G-ApaI/C-FokI/A) haplotypes were significantly more frequent in the PTN mothers, whereas the GG genotype of TaqI and the CT genotype of the BsmI SNVs, and the GCG (TaqI/GApaI/C-FokI/G) haplotype were more frequent in the FTN mothers. With regard to the relationship between $25(\mathrm{OH}) \mathrm{D}$ levels and the genotypes of the gene $V D R$ variants, the PTN mothers with the AG genotype of the TaqI, the AA genotype of the ApaI, and the AG genotype of the FokI SNVs had significantly lower 25(OH) D levels. Mothers with the TT variant genotype of the BsmI and the AA genotype of the ApaI SNVs with $25(\mathrm{OH})$ D deficiency had an increased risk of preterm birth, whereas the carriers of the GG genotype of the TaqI SNV had a lower risk.
In the newborns, the TT genotype of the BsmI, the AA genotype of the ApaI, the GG genotype of the Fokl SNVs, and the GAG (TaqI/G-ApaI/A-FokI/G) haplotype was significantly more frequent in the PTN group, whereas the frequencies of the CT genotype of the BsmI SNV and the GCA (TaqI/G-ApaI/C-FokI/A) haplotype were significantly higher in the FTN group. The PTN carriers of the GG genotype of the FokI SNV had significantly lower $25(\mathrm{OH})$ D levels.

The genotypes of the BsmI variant deviated from HWE in the PTNs mothers and their newborns. HardyWeinberg disequilibrium may indicate genotyping errors, population stratification, or selection bias [49]. However, the studied variants were identified by qPCR using TaqMan probes, which is a validated and robust methodology. This finding may indicate a possible association between the marker locus and the risk of prematurity.

Conflicting results can be attributed to important differences between studies. Ethnicity is an important factor in SNV prevalence among different geographic populations, and is especially important in admixed populations such as the Brazilian population. Brazil is a country of continental dimensions; it covers 8,516,000 $\mathrm{km}^{2}$, and is inhabited by more than 200 million people. Brazilian population origins traces back to the former Amerindians and the main sources of immigration, specially western-european and African [50]. With regard to 
the five geographical regions of Brazil (North, Northeast, Central-West, Southeast, and South), ancestry from North Brazil is mostly amerindian, Northeast and Central-West mainly African, and Southern and Southeastern predominantly European. For decades, new immigrants and migrants from other parts of Brazil have flocked to Southeast Brazil, where intermarriage between individuals of different ancestries is very common [50]. This could explain the differences between the findings presented here - which are based on a population from the Southeast region of Brazil - and those of Javorski et al. (2018) [21] - which were also based on a Brazilian population, but from the Northeast region, although none of these studies evaluated the ancestral origin of the studied population.

Moreover, the variants studied in the different publications were not the same, and the genetic nomenclature used in some studies was diverse from described in the Human Genome Variation Society (HGVS) [29] - which hindered the interpretation of the results. Thus, the studied groups are heterogeneous, which may make their interpretation and comparison difficult.

Considering the potential limitations of the present study, the main concern could be considered the sample size. Nevertheless, this is the first study to associate serum vitamin $\mathrm{D}$ concentrations and $V D R$ gene variants with the risk of prematurity (less than 32 weeks' gestation). In addition, we observed that a maternal variable, specific hypertension disease in pregnancy was significantly more frequent in PTN mothers that can be a possible confounding factors and may influence the levels of $25(\mathrm{OH}) \mathrm{D}$ and risk of prematurity. Despite that, we observed that mothers carriers of the BsmI/TT and ApaI/ AA SNVs, individually or associated with vitamin D deficiency, had an increased chance of preterm birth.

\section{Conclusions}

$V D R$ gene variants help explain the variations in the levels of $25(\mathrm{OH}) \mathrm{D}$ in relation to the risk of prematurity in the studied population. The variant genotypes of the BsmI/TT and ApaI/AA SNVs, individually or associated with vitamin D deficiency, were associated with the increased risk of prematurity. Preterm newborns with the GG genotype of the FokI SNV had lower serum 25(OH) D concentrations.

\section{Abbreviations}

BMI: Body mass index (BMI); Cl: Confidence interval;

EDTA: Ethylenediaminetetraacetic acid; FTN: Full-term newborn; HWE: HardyWeinberg equilibrium; OR: Odds ratio; PTB: Preterm birth; PTN: Preterm newborn; SNV: Single nucleotide variation; VDR: Vitamin D receptor; Vitamin D: $25(\mathrm{OH}) \mathrm{D}$

\section{Acknowledgments}

The authors thank Dr. Fernando Adami for his assistance in the statistical analyses.

\section{Authors' contributions}

LVD, BB, and FISS conceived the study and prepared the proposal. LVD, FAFK, FRC, MSK, and FISS collected the data. LVD, BB, FISS and FWSF analyzed the data. LVD, BB, FISS, and CPB interpreted the data. All authors contributed to the identification and critical evaluation of the relevant literature, and to drafting the manuscript and approving its final version.

\section{Funding}

This work was supported by FAPESP \#15/15399-1 and the grant was allocated to cost the Kits for clinical analysis (analysis of the samples). This work was also supported by CNPq \#403704/2016-2 and the grant was allocated to costs the genotyping (analysis of the samples: Taql, Bsml, Apal, and FokI VDR variants). The authors thank CAPES for granting Letícia Veríssimo Dutra a scholarship. These funding bodies only provided the financial means to allow the authors to carry out the study. The funding bodies played no role in the design of the study and collection, analysis, and interpretation of data and in writing the manuscript.

\section{Availability of data and materials}

The datasets generated and/or analysed during the current study are available in the Mendeley repository at https://data.mendeley.com/datasets/ b69mpd2yhb/1. DOI: https://doi.org/10.17632/b69mpd2yhb.1.

\section{Ethics approval and consent to participate}

This study was approved by the Faculdade de Medicina do ABC's institutional ethics committee (CAAE: 54166216.5.0000.0082). The study was performed under Helsinki's ethical principle. Informed written consent was obtained from each mother. The infant's parents signed and dated the written informed consent form for the infant's participation in the study.

\section{Consent for publication}

Not applicable.

\section{Competing interests}

The authors declare that they have no competing interests.

\section{Author details}

${ }^{1}$ Postgraduation Program in Health Sciences, Faculdade de Medicina do ABC, Santo Andre, Brazil. ${ }^{2}$ Medical Student, Faculdade de Medicina do ABC, Santo Andre, Brazil. ${ }^{3}$ Department of Pediatrics, Discipline of Pediatrics, Faculdade de Medicina do ABC, Santo André, Brazil. ${ }^{4}$ Department of Collective Health, Discipline of Sexual and Reproductive Health and Populational Genetics, Faculdade de Medicina do ABC, Santo Andre, Brazil.

Received: 23 April 2019 Accepted: 11 December 2019

\section{1.}

\section{References}

1. Blencowe H, Cousens S, Oestergaard MZ, Chou D, Moller AB, Narwal R, et al. National, regional, and worldwide estimates of preterm birth rates in the year 2010 with time trends since 1990 for selected countries: a systematic analysis and implications. Lancet. 2012;379(9832):2162-72.

2. WHO. Preterm birth http://www.who.int/en/news-room/fact-sheets/detail/ preterm-birth, World Health Organization, 2018.

3. Oliveira LL, Gonçalves AC, Costa JS, Bonilha AL. Maternal and neonatal factors related to prematurity. Rev Esc Enferm USP. 2016;50(3):382-9.

4. Blencowe H, Cousens S, Chou D, Oestergaard M, Say L, Moller AB, et al, Born too soon: the global epidemiology of 15 million preterm births. Reprod Health. 2013;10(Suppl 1):S2.

5. Tielsch JM. Global incidence of preterm birth. Nestle Nutr Inst Workshop Ser. 2015;81:9-15.

6. Oliveira RR, Melo EC, Fujimori E, Mathias TA. The inner state differences of preterm birth rates in Brazil: a time series study. BMC Public Health. 2016;16:411.

7. Christakos S, Dhawan P, Verstuyf A, Verlinden L, Carmeliet G. Vitamin D: Metabolism, molecular mechanism of action, and pleiotropic effects. Physiol Rev 2016:96(1):365-408.

8. Bouillon R, Carmeliet $G$, Verlinden L, van Etten E, Verstuyf $A$, Luderer HF, et al. Vitamin $D$ and human health: lessons from vitamin $D$ receptor null mice. Endocr Rev. 2008;29(6):726-76. 
9. Wang $H$, Chen W, Li D, Yin X, Zhang X, Olsen N, et al. Vitamin D and chronic diseases. Aging Dis. 2017;8(3):346-53.

10. Fleet JC. The role of vitamin $\mathrm{D}$ in the endocrinology controlling calcium homeostasis. Mol Cell Endocrinol. 2017;453:36-45.

11. Pfotenhauer KM, Shubrook JH. Vitamin D deficiency, its role in health and disease, and current supplementation recommendations. J Am Osteopath Assoc. 2017;117(5):301-5

12. Aghajafari F, Nagulesapillai T, Ronksley PE, Tough SC, O'Beirne M, Rabi DM. Association between maternal serum 25 -hydroxyvitamin $D$ level and pregnancy and neonatal outcomes: systematic review and meta-analysis of observational studies. BMJ. 2013;346:f1169.

13. Hossein-nezhad A, Holick MF. Vitamin D for health: a global perspective. Mayo Clin Proc. 2013;88(7):720-55.

14. Prado MR. Oliveira FeC, Assis KF, Ribeiro SA, do Prado junior PP, Sant'Ana LF, et al. [prevalence of vitamin D deficiency and associated factors in women and newborns in the immediate postpartum period]. Rev Paul Pediatr. 2015; 33(3):287-94.

15. Whitfield GK, Hsieh JC, Nakajima S, MacDonald PN, Thompson PD, Jurutka $\mathrm{PW}$, et al. A highly conserved region in the hormone-binding domain of the human vitamin $\mathrm{D}$ receptor contains residues vital for heterodimerization with retinoid $\mathrm{X}$ receptor and for transcriptional activation. Mol Endocrinol. 1995;9(9):1166-79.

16. Bandera Merchan B, Morcillo S, Martin-Nuñez G, Tinahones FJ, MacíasGonzález M. The role of vitamin D and VDR in carcinogenesis: through epidemiology and basic sciences. J Steroid Biochem Mol Biol. 2017;167: 203-18.

17. Manzon L, Altarescu G, Tevet A, Schimmel MS, Elstein D, Samueloff A, et al. Vitamin $D$ receptor polymorphism Fokl is associated with spontaneous idiopathic preterm birth in an Israeli population. Eur J Obstet Gynecol Reprod Biol. 2014;177:84-8.

18. Cai W, Shen XY, Zhu BP, Pan SL. Relationship between vitamin D receptor gene polymorphism and preterm birth. Nan Fang Yi Ke Da Xue Xue Bao. 2016;36(9):1276-80.

19. Baczyńska-Strzecha M, Kalinka J. Assessment of correlation between vitamin $D$ level and prevalence of preterm births in the population of pregnant women in Poland. Int J Occup Med Environ Health. 2017;30(6):933-41.

20. Rosenfeld T, Salem H, Altarescu G, Grisaru-Granovsky S, Tevet A, Birk R. Maternal-fetal vitamin $D$ receptor polymorphisms significantly associated with preterm birth. Arch Gynecol Obstet. 2017;296(2):215-22.

21. Javorski N, Lima CAD, Silva LVC, Crovella S, de Azêvedo Silva J. Vitamin D receptor (VDR) polymorphisms are associated to spontaneous preterm birth and maternal aspects. Gene. 2018;642:58-63.

22. Barchitta M, Maugeri A, La Rosa MC, Magnano San Lio R, Favara G, Panella $M$, et al. Single Nucleotide Polymorphisms in Vitamin D Receptor Gene Affect Birth Weight and the Risk of Preterm Birth: Results from the "Mamma \& Bambino" Cohort and A Meta-Analysis. Nutrients. 2018;10(9).

23. Wang S, Ray N, Rojas W, Parra MV, Bedoya G, Gallo C, et al. Geographic patterns of genome admixture in Latin American mestizos. PLoS Genet. 2008;4(3):e1000037.

24. Salzano FM, Sans M. Interethnic admixture and the evolution of Latin American populations. Genet Mol Biol. 2014;37(1 Suppl):151-70.

25. Villar et al. International standards for newborn weight, length, and head circumference by gestational age and sex: the newborn cross-sectional study of the INTERGROWTH-21st project. Lancet 2014;384(9946):857-868,

26. Villar et al. International Fetal and Newborn Growth Consortium for the 21st Century INTERGROWTH-21st, 2015.

27. WHO. Guideline: Vitamin D Supplementation in Pregnant Women. World Health Organization, 2012.

28. Lahiri DK, Nurmberger JI Jr. A rapid non-enzymatic method for the preparation of HMW DNA from blood for RFLP studies. Nucleic Acids Res. 1991;19(19):5444.

29. den Dunnen JT, Dalgleish R, Maglott DR, Hart RK, Greenblatt MS, McGowanJordan J, et al. HGVS recommendations for the description of sequence variants: 2016 update. Hum Mutat. 2016;37(6):564-9.

30. Larqué $E$, Morales $E$, Leis $R$, Blanco-Carnero JE. Maternal and Foetal health implications of vitamin D status during pregnancy. Ann Nutr Metab. 2018; 72(3):179-92.

31. Qin LL, Lu FG, Yang SH, Xu HL, Luo BA. Does Maternal Vitamin D Deficiency Increase the Risk of Preterm Birth: A Meta-Analysis of Observational Studies. Nutrients. 2016;8(5).
32. von Websky K, Hasan AA, Reichetzeder C, Tsuprykov O, Hocher B. Impact of vitamin $\mathrm{D}$ on pregnancy-related disorders and on offspring outcome. J Steroid Biochem Mol Biol. 2018;180:51-64.

33. Zhou SS, Tao YH, Huang K, Zhu BB, Tao FB. Vitamin D and risk of preterm birth: up-to-date meta-analysis of randomized controlled trials and observational studies. J Obstet Gynaecol Res. 2017;43(2):247-56.

34. Woo J, Giurgescu C, Wagner CL. Evidence of an association between vitamin $\mathrm{D}$ deficiency and preterm birth and preeclampsia: a critical review. Midwifery Womens Health. 2019; [Epub ahead of print].

35. Gilman-Sachs A, Dambaeva S, Salazar Garcia MD, Hussein Y, Kwak-Kim J, Beaman K. Inflammation induced preterm labor and birth. J Reprod Immunol. 2018;129:53-8.

36. Mirzakhani H, Litonjua AA, McElrath TF, O'Connor G, Lee-Parritz A, Iverson R, et al. Early pregnancy vitamin D status and risk of preeclampsia. J Clin Invest. 2016:126(12):4702-15.

37. Gernand AD, Simhan HN, Baca KM, Caritis S, Bodnar LM. Vitamin D, preeclampsia, and preterm birth among pregnancies at high risk for preeclampsia: an analysis of data from a low-dose aspirin trial. BJOG. 2016; 124(12):1874-82.

38. Wagner CL, Taylor SN, Dawodu A, Johnson DD, Hollis BW. Vitamin D and its role during pregnancy in attaining optimal health of mother and fetus. Nutrients. 2012:4(3):208-30.

39. Weinert LS, Silveiro SP. Maternal-fetal impact of vitamin D deficiency: a critical review. Matern Child Health J. 2015;19(1):94-101.

40. Achkar M, Dodds L, Giguère Y, Forest JC, Armson BA, Woolcott C, et al. Vitamin D status in early pregnancy and risk of preeclampsia. Am J Obstet Gynecol. 2015;212(4):511.e1-7.

41. Redman C, Sacks GP, Sargent IL. Preeclampsia: an excessive maternal inflammatory response to pregnancy. Am J Obstet Gynecol. 1999;180: 499-506.

42. Palacios C, Kostiuk LK, Peña-Rosas JP. Vitamin D supplementation for women during pregnancy. Cochrane Database Syst Rev. 2019;7:CD008873.

43. Xu J, Gu Y, Lewis DF, Cooper DB, McCathran CE, Wang Y. Downregulation of vitamin D receptor and miR-126-3p expression contributes to increased endothelial inflammatory response in preeclampsia. J Reprod Immunol. 2019; [Epub ahead of print].

44. Farajian-Mashhadi F, Eskandari F, Rezaei M, Eskandari F, Najafi D, Teimoori B, et al. The possible role of maternal and placental vitamin D receptor polymorphisms and haplotypes in pathogenesis of preeclampsia. Clin Exp Hypertens. 2019 [Epub ahead of print].

45. Committee ACOG. On obstetric practice. Committee opinion no. 495. Vitamin D: screening and supplementation during pregnancy. Obstet Gynecol. 2011;118(1):197-8.

46. Institute of Medicine. In: Ross C, Taylor CL, Yaktine Ann L, Del Valle HB, editors. Dietary reference intakes for calcium and vitamin D. Washington, DC: The National Academies Press Institute of Medicine; 2011. https://www. nap.edu/catalog/13050/dietary-reference-intakes-forcalcium-and-vitamin-d. Accessed on November 2018.

47. Holick MF, Binkley NC, Bischoff-Ferrari HA, Gordon CM, Hanley DA, Heaney RP, Murad MH. Weaver CM; Endocrine Society. Evaluation, treatment and prevention of vitamin D deficiency: an Endocrine Society clinical practice guideline. J Clin Endocrinol Metab. 2011;96(7):1911-30.

48. World Health Organization. Guideline: Vitamin D Supplementation in Pregnant Women. Geneva, Switzerland: World Health Organization; 2016. http://apps.who.int/iris/bitstream/handle/10665/85313/9789241504935_eng. pdf?ua=1. Updated November 2016. Accessed November 2018.

49. Hosking L, Lumsden S, Lewis K, Yeo A, McCarthy L, Bansal A, et al. Detection of genotyping errors by hardy-Weinberg equilibrium testing. Eur J Hum Genet. 2004;12(5):395-9.

50. Giolo SR, Soler JM, Greenway SC, Almeida MA, de Andrade M, Seidman JG, et al. Brazilian urban population genetic structure reveals a high degree of admixture. Eur J Hum Genet. 2012;20(1):111-6.

\section{Publisher's Note}

Springer Nature remains neutral with regard to jurisdictional claims in published maps and institutional affiliations. 